\title{
A new species of Spariolenus from South Iran (Aranei: Sparassidae)
}

\author{
Новый вид рода Spariolenus из южжного Ирана \\ (Aranei: Sparassidae)
}

\author{
Alireza Zamani \\ А. Замани \\ School of Biology, College of Sciences, University of Tehran, Tehran, Iran. E-mail: zamani.alireza5@gmail.com \\ KEY WORDS: spiders, Araneae, Asia, Middle East. \\ КЛЮЧЕВЫЕ СЛОВА: пауки, Araneae, Азия, Ближний Восток.
}

ABSTRACT. A new species of Spariolenus Simon, 1880, S. khoozestanus sp.n., is described and illustrated on the basis of a female holotype from Khuzestan Province, southwestern Iran. It is the $10^{\text {th }}$ species of the genus.

PЕЗЮМЕ. Описан новый вид Spariolenus khoozestanus sp.n. на основе голотипа (самки) из провинции Хузестан, южный Иран. Это 10-й вид рода.

\section{Introduction}

Spariolenus Simon, 1880 is a small genus of medium to very large-sized sparassid spiders, currently comprising nine species distributed from western Iran to Sumatra [WSC, 2016]. This genus is relatively wellstudied in Iran due to an extensive survey by Moradmand \& Jäger [2011] in which four new species were described from the western and southern parts of the Zagros Mountains. As a result of further investigation of the spider fauna of southwestern Iran, an undescribed species was found in the material, which is described and illustrated here, raising the number of sparassid species known from this country to 13 [Zamani et al., 2016].

\section{Material and method}

Illustrations were produced using an Olympus Camedia E-520 camera attached to an Olympus SZX16 stereomicroscope at the Zoological Museum of University of Turku. To provide a complete depth of field, several images were combined using Zerene Stacker focus stacking software. All measurements are in $\mathrm{mm}$. The depository of the studied material is the Senckenberg Museum, Frankfurt am Main (SMF). Terminology follows Moradmand \& Jäger [2011].

\section{Systematic part}

Family Sparassidae Bertkau, 1872

Genus Spariolenus Simon, 1880

Spariolenus khoozestanus sp.n.

Figs 1-5.

TYPE MATERIAL. Holotype + (SMF), IRAN: Khuzestan Province: Lali Co., 32 $12^{\circ} 44^{\prime \prime}$ N 4905'37" E, 6.11 .2015 (S. Sami).

ETYMOLOGY. The specific epithet refers to the type locality.

DIAGNOSIS. The new species is most similar to $S$. tigris Simon, 1880, with a known distribution of Pakistan to Malaysia. The two species can be easily separated by the shape of epigyne: 1) posterior part of the upper coil $(P u c)$ of the insemination ducts is long and semi-horizontal in the new species (Fig. 3), whereas it is short and vertically inclined in S. tigris [Jäger, 2006: fig. 13]; 2) the ducts of the middle coil (Mcd) are kidney-shaped in both species, but short, with the lobes close together in the new species, whereas in S. tigris they are long and more widely separated; 3 ) unlike in $S$. tigris, in the new species the central rims extend laterally beyond the copulatory openings (Fig. 4); 4) in $S$. tigris, the posterior margins of the epigynal plate $(P m f)$ are close together, whereas in the new species they are widely separated [Jäger, 2006: fig. 12].

DESCRIPTION. Female: body length 22.83; carapace 11.80 long, 10.70 wide. ALE 1.02, AME 0.37, PLE 1.05, PME 0.55, AME-AME 0.45, PME-PME 0.52. Sternum 5.40 long, 4.70 wide. Leg I: 51.1 [14.2 5.914 .713 .4 2.9]. Prosoma as in Fig. 1. General body coloration light yellowish brown with scattered dark brown spots and markings on the carapace and dorsum of the opisthosoma. Legs with dark brown bands. Spination (excluding metatarsi): leg I: femur $3 \mathrm{p}, 1 \mathrm{~d}, 3 \mathrm{r}$, patella $1 \mathrm{p}, 1 \mathrm{r}$, tibia $10 \mathrm{v}$; leg II: femur $4 \mathrm{p}, 2 \mathrm{~d}, 4 \mathrm{r}, 2 \mathrm{v}$, patella $1 \mathrm{p}$, $1 \mathrm{r}$, tibia $10 \mathrm{v}$; leg III: femur $4 \mathrm{p}, 2 \mathrm{~d}, 3 \mathrm{r}$, patella $1 \mathrm{p}, 1 \mathrm{r}$, tibia $1 \mathrm{p}, 1 \mathrm{r}, 8 \mathrm{v}$; leg IV femur $3 \mathrm{p}, 2 \mathrm{~d}, 2 \mathrm{r}$, 

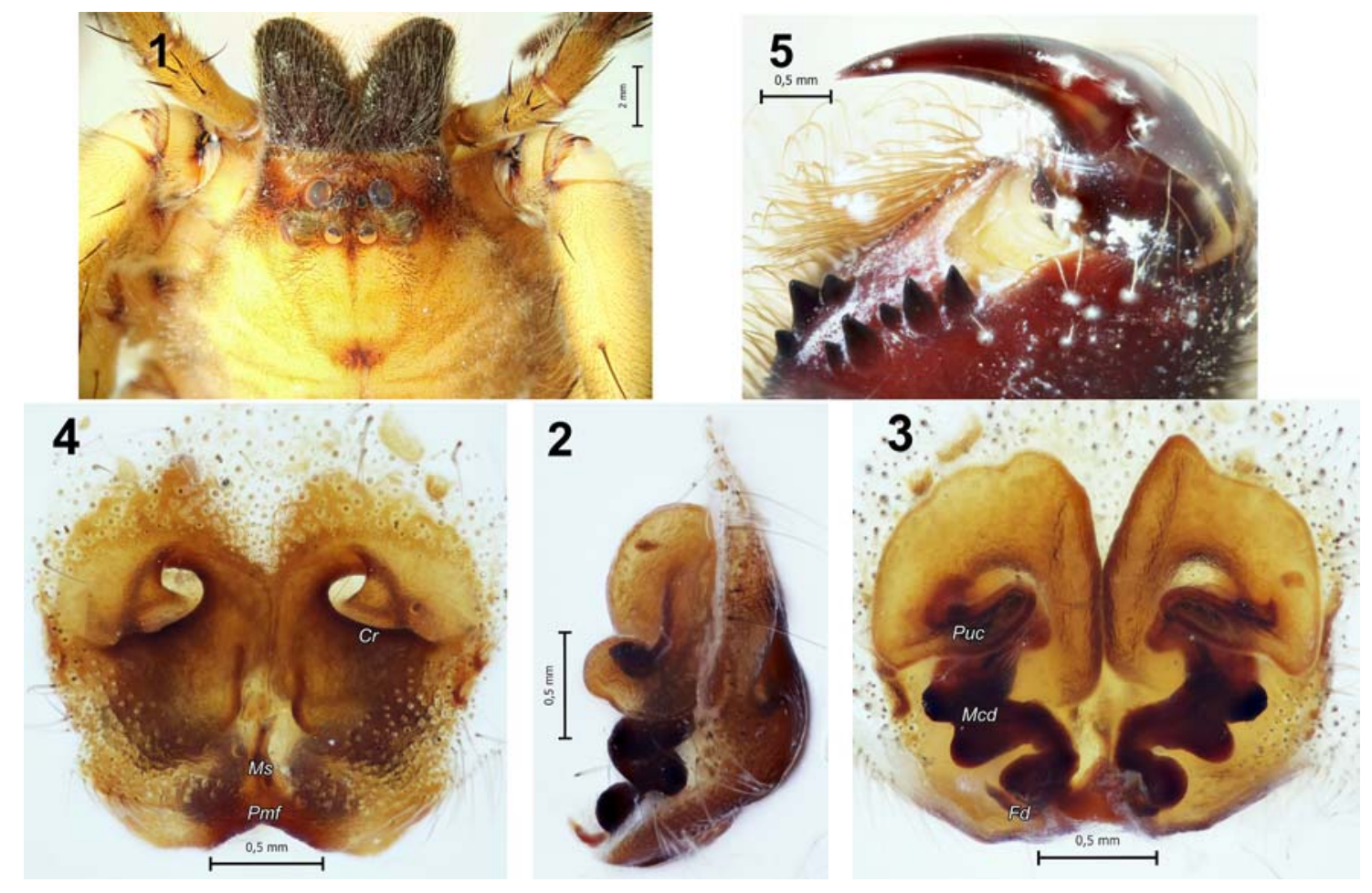

Figs 1-5. Spariolenus khoozestanus sp.n., holotype female: 1 - carapace, dorsal; 2 - epigyne, lateral; 3 - epigyne, dorsal; 4 epigyne, ventral; 5 - left chelicera, ventral. Abbreviations: $C r$ - central rim; $F d$ - fertilization duct; $M c d$ - duct of middle coil; $M s-$ median slit; Pmf - posterior margin of epigynal plate; Puc — posterior part of upper coil.

Рис. 1-5. Spariolenus khoozestanus sp.n., голотип, самка: 1 - карапакс, дорзально; 2 - эпигина, сбоку; 3 - эпигина, сверху; 4 - эпигина, снизу; 5 - левая хелицера, снизу. Сокращения: $C r$ - центральный ободок; $F d$ - оплодотворительный канал; $M c d$ - трубка средней петли; $M s$ - срединная щель; Pmf — задний край пластинки эпигины; Рuc — задняя часть верхней петли.

patella $1 \mathrm{p}$, tibia $2 \mathrm{p}, 2 \mathrm{~d}, 2 \mathrm{r}, 6 \mathrm{v}$. Chelicerae with 3 anterior and 5 posterior teeth; cheliceral furrow with denticles, most of which are near the anterior teeth (Fig. 5). Palpal claw with first tooth longer than secondary teeth, 5 secondary teeth present.

Epigyne as in Figs 2-4. Copulatory openings wide and spirally coiled. Central rims $(\mathrm{Cr})$ close to copulatory openings, extending laterally beyond them. Median slit $(M s)$ long. Posterior margin of epigynal plate wide and separated. Ducts of upper coil of insemination loops wide and close together; middle coil $(\mathrm{Mcd})$ long, broad and semi-horizontal in the posterior part; lower ducts short and kidney-shaped. Fertilization ducts $(F d)$ relatively long and narrow.

Male: Unknown.

DISTRIBUTION. Known only from the type locality in Khuzestan, southwestern Iran.

ACKNOWLEDGMENTS. I am grateful to anonymous reviewers and the responsible editor for their comments which improved the manuscript, Seppo Koponen for providing research facilities at the Zoological Museum of Turku and Soheyl Sami for giving me the collected material. English of the final draft was kindly checked and corrected by Sarah Crews (San Francisco, USA).

\section{References}

Jäger P. 2002. Heteropodinae: transfers and synonymies (Arachnida: Araneae: Sparassidae)// Acta Arachnologica. Vol.51. No.1. P.33-61.

Jäger P. 2006. A new Spariolenus species from caves in Oman the first representative of the Heteropodinae in the Arabian peninsula (Araneae: Sparassidae) // Bulletin of the British Arachnological Society. Vol.13. Pt.8. P.309-313.

Moradmand M., Jäger P. 2011. A review on the huntsman spider genus Spariolenus Simon, 1880 (Araneae: Sparassidae: Heteropodinae) in Iran with description of four new species // Zootaxa. Vol.2910. P.46-62.

WSC 2016. World Spider Catalog. Natural History Museum Bern. Online at http://wsc.nmbe.ch, version 17.5. (accessed 8 September 2016).

Zamani A., Mirshamsi O., Marusik Y.M., Moradmand M. 2016. The Checklist of the Spiders of Iran. Version 2016. Online at http://www.spiders.ir (accessed 8 September 2016).

Responsible editor K.G. Mikhailov 